\title{
Anti-Inflammatory Effects of Ethyl Acetate Fraction from Cnidium officinale Makino on LPS-Stimulated RAW 264.7 and THP-1 Cells
}

\author{
Jin Boo Jeong, Se Chul Hong, Hyung Jin Jeong and Jin Suk Koo* \\ Medicinal Plant Resources Major, Andong National University, Andong 760-749, Korea
}

\begin{abstract}
This work aimed to elucidate the anti-inflammatory effects of ethyl acetate fraction from Cnidium officinale Makino with a cellular system of LPS-stimulated RAW 264.7 and THP-1 cells. Some key pro-inflammatory cytokines and mediators including NO, iNOS, PGE 2 , COX-2, TNF- $a, N F-\kappa B$ p50 and NF- $\kappa$ B p 65 were studied by sandwich ELISA and western blot analysis. Ethyl acetate fraction could significantly inhibit the production of NO, PGE 2 , TNF-a, iNOS and COX-2 in LPS-stimulated cell than that of single LPS-stimulated. And ethyl acetate fraction suppresses the activation of NF- $\kappa$ B p50 and NF- $\mathrm{B}$ p65. All the results showed that ethyl acetate fraction had a good anti-inflammatory effect on LPS-stimulated RAW264.7 and THP-1 cells. Taken together, the anti-inflammatory actions of ethyl acetate fraction from Cnidium officinale Makino might be due to the down-regulation of NO, PGE 2 , TNF-a, iNOS and COX-2 via the suppression of NF- $\mathrm{KB}$ activation.
\end{abstract}

Key words - Cnidium officinale, NO, $\mathrm{PGE}_{2}, \mathrm{TNF}-\mathrm{a}, \mathrm{NF}-\kappa \mathrm{B}$

\section{Introduction}

Innate immunity is an ancient form of host defense that is activated rapidly to enable, through a multiplicity of effector mechanisms, defense against bacterial or viral infections and stresses; however, excessive innate immunity responses may cause conditions such as sepsis and chronic inflammation (Nathan, 2002). Upon inflammatory stimulation, macrophages produce nitric oxide (NO), prostaglandin $\mathrm{E}_{2}\left(\mathrm{PGE}_{2}\right)$ and pro-inflammatory cytokines such as tumor necrosis factor (TNF)-alpha. Overproduction of these mediators is present in macrophage of many inflammatory diseases, including rheumatoid arthritis, atherosclerosis, and hepatitis (Libby et al., 2002).

NO, which plays as an important cellular second messenger, is produced via three types of nitric oxide synthase (NOS). Small amounts of NO produced by the constitutive NOS (cNOS) are essential for maintaining the cellular function. Inducible NOS (iNOS) can sustainedly produce a high output of NO, which is believed as one of the most important inflammatory reactions in activated macrophage

${ }^{\star}$ Corresponding author. E-mail : kimkoo1114@andong.ac.kr
(Sim et al., 2010; Pokharel et al., 2007). In addition, the inducible cyclooxygenase-2 (COX-2) is believed to be the target enzyme for the anti-inflammatory activity. Many studies have demonstrated that some inducible enzyme (COX and iNOS)/cytokines and their reaction products are involved in chronic inflammatory disease (Zhao et al., 2009). Improper up-regulation of iNOS and/or COX-2 is associated to pathophysiology of certain types of cancers as well as inflammatory disorders (Yang et al., 2006).

Most clinically important medicines are steroidal or nonsteroidal anti-inflammatory chemical therapeutics for treatment of inflammation-related diseases. Though these have potent activity, long-term administration is required for treatment of chronic disease. Furthermore, these drugs have various and severe adverse effects. Therefore, naturally occurring agents, with high effectiveness and very few side-effects, are desirable as substitutes for chemical therapeutics. Many new drugs derived from plant secondary metabolites have been applied for the treatment and/or prevention of various diseases. Investigations about natural products have recently regained prominence with the increasing understanding of their biological significance and increasing recognition of their origin and structural diversity (Menichini et al., 2009). 
The dried rhizome of Cnidium officinale Makino has been used as herbal drugs to treat pain, menstrual disturbance, blood pressure depressant and a deficiency disease of antivitamin. In addition, there are several reports suggesting that they have pharmacological properties to tumor metastasis and angiogenesis (Ahn et al., 2000; Lim et al., 2011) and an inhibitor of high glucose-induced proliferation of glomerular mesangial cells (Jeong et al., 2005). However, little has been known about the functional role of ethyl acetate fraction from COM against the inflammation in lipopolysaccharide (LPS)stimulated RAW 264.7 and THP-1 cells. In addition, the underlying mechanisms that account for their anti-inflammatory activity and active components remain largely un-elucidated

In this study, therefore, the modulating effect of Cnidium officinale Makino on the cellular inflammatory events was examined in order to understand its potential anti-inflammatory mechanisms within pharmacologically non-cytotoxic concentration levels.

\section{Materials and Methods}

\section{Sample preparation and extraction}

The plant sample, $C$. officinale was kindly provided by the Bonghwa Alpine Medicinal Plant Experiment Station, Korea. The voucher specimens of plant samples were deposited at the major, medicinal resources, Andong National University, Andong, Korea. One kilogram of dried rhizomes was extracted with $2000 \mathrm{ml}$ of $80 \%$ methanol with shaking for 24 hours. After 24 hours, the methanol-soluble fraction was filtered and concentrated to approximately $400 \mathrm{ml}$ volume using by a vacuum evaporator and fractioned in a separating funnel. The ethyl acetate fraction was separated from the mixture, evaporated by a vacuum evaporator and kept in a refrigerator for further experiments

\section{GC/MS analysis}

GC/MS analysis for the compositions of ethyl acetate fraction from $C$. officinale was performed using same $\mathrm{GC} /$ MSD, equipped with a Supelcowax 10 fused silica capillary (30 m length $\times 0.25 \mathrm{~mm}$ i.d. supelco, USA). The carrier gas used was helium, at a constant flow rate of $1.0 \mathrm{ml} / \mathrm{min}$. One microliter of the extract was injected into the column using
10:1 of the split ratio injection mode. The oven temperature was initially held at $50^{\circ} \mathrm{C}$ for $0 \mathrm{~min}$, then raised to $240^{\circ} \mathrm{C}, 2^{\circ} \mathrm{C}$ $/ \mathrm{min}$, and finally held at $240^{\circ} \mathrm{C}$ for $5 \mathrm{~min}$. The temperatures of injector and detector were $200^{\circ} \mathrm{C}$ and $240{ }^{\circ} \mathrm{C}$, respectively. The mass detector was operated in electron impact mode with an ionization energy of $70 \mathrm{eV}$, a scanning range of 33-550 a.m.u. and a scan rate of 1.4 scans/s. Components of the extracts were identified with the aid of the database (Wiley 275 Imass spectral database, Hewlett-Packard, 1995) or by manual interpretation.

\section{Cell culture}

RAW264.7 cells, a mouse peritoneal macrophage line, were purchase from American Type Culture Collection (ATCC, Rockville, MD, USA) and maintained in a $5 \% \mathrm{CO}_{2}$ atmosphere in Dulbecco's modified Eagle's medium (DMEM; GibcoBRL, Grand Island, NY, USA) supplemented with 5\% heat-inactivated fetal bovine serum (FBS), $100 \mu \mathrm{g} / \mathrm{ml}$ streptomycin, and $100 \mathrm{U} / \mathrm{ml}$ penicillin (GibcoBRL). THP-1 human monocyte-macrophage (ATCC TIB-202) was maintained in RPMI 1640 medium supplemented with 5\% FBS, $100 \mu \mathrm{g} / \mathrm{ml}$ of streptomycin, and $100 \mathrm{U} / \mathrm{ml}$ of penicillin in a $5 \% \mathrm{CO}_{2}$ atmosphere. The medium for RAW 264.7 cells and THP-1 cells was routinely changed every two day. RAW 264.7 and THP-1 cells were passaged by trypsinization until they attained confluence.

\section{Cell viability assay}

To determine the effect of ethyl acetate fraction on cell viability, RAW 264.7 cells and THP-1 cells were seeded in a 96-well plates at a density of $5 \times 10^{4}$ cells/well. Ethyl acetate fraction was added at serially indicated concentrations. Control group was treated with an equal amount of DMSO, which resulted in a final concentration of $0.3 \% \mathrm{DMSO}$ in the medium. At 24 hours after the treatment of ethyl acetate fraction, a MTT solution was added and then the cells were incubated for another 4 hours at $37^{\circ} \mathrm{C}$. After removing the medium, 100 $\mu 1$ of DMSO was added to the cells. The absorbance was measured by using a microplate reader at $450 \mathrm{~nm}$. The control group consisted of untreated cells was considered as $100 \%$ of viable cells. Results are expressed as percentage of viable cells when compared with control groups. 


\section{Detemination of $\mathrm{NO}$ and $\mathrm{PGE}_{2}$ production}

Inhibitory effect on NO production by murine macrophagelike RAW 264.7 cells was evaluated using a method modified from that previously reported (Banskota et al., 2003). Briefly, the RAW 264.7 cells $\left(2 \times 10^{5}\right.$ cells/well $)$ in $10 \%$ FBS-DMEM without phenol red were seeded in a 6-well plate for 24 hours at $37^{\circ} \mathrm{C}$. Cells were washed with $1 \times \mathrm{PBS}$, replaced with fresh media, and then treated with the varying concentrations of the ethyl acetate fraction for $30 \mathrm{~min}$. After $30 \mathrm{~min}$, LPS $(1 \mu \mathrm{g} / \mathrm{ml})$ was treated for 24 hours at $37^{\circ} \mathrm{C}$. At 24 hours after LPS treatment, $100 \mu \mathrm{l}$ of the medium were placed in a 96 well plate and an equal amount of Griess reagent ( $1 \%$ sulfanilamide and $0.1 \% \mathrm{~N}-1$-(naphthyl) ethylenediamine-diHCl in $2.5 \% \mathrm{H}_{3} \mathrm{PO}_{4}$ ) was added. The plate was incubated for additional $5 \mathrm{~min}$ at the room temperature and then the absorbance was measured at $540 \mathrm{~nm}$ with the microplate reader. The amount of NO was calculated using sodium nitrite standard curve. For the measurement of $\mathrm{PGE}_{2}$ production, $50 \mu \mathrm{l}$ of the supernatant of cultured medium was collected, and $\mathrm{PGE}_{2}$ production was determined using $\mathrm{PGE}_{2}$ ELISA monoclonal (Cayman Chemical, Ann Arbor, MI) with manufacturer's instructions.

\section{Determination of TNF- $\alpha$ release}

THP-1 cells $\left(2 \times 10^{5}\right.$ cells/well $)$ in $10 \%$ FBS-RPMI 1640 were seeded in a 6 -well plate for 24 hours at $37^{\circ} \mathrm{C}$. Cells were washed with $1 \times \mathrm{PBS}$, replaced with fresh media, and then treated with the varying concentrations of ethyl acetate fraction for $30 \mathrm{~min}$. After $30 \mathrm{~min}$, LPS $(1 \mu \mathrm{g} / \mathrm{ml})$ was treated for 24 hours at $37^{\circ} \mathrm{C}$. At 24 hours after LPS treatment, $50 \mu \mathrm{l}$ of the supernatant of cultured medium was collected, and TNF- $a$ was determined using Human TNF- $a$ ELISA kit (R\&D systems, Minneapolis, $\mathrm{MN}$ ) with manufacturer's instructions.

\section{Determination of NF- $\kappa$ B activation}

THP- 1 cells $\left(2 \times 10^{5}\right.$ cells/well $)$ in 10\% FBS-RPMI 1640 were seeded in a 6 -well plate for 24 hours at $37^{\circ} \mathrm{C}$. Cells were washed with $1 \times$ PBS, replaced with fresh media, and then treated with the varying concentrations of ethyl acetate for 30 $\min$. After $30 \mathrm{~min}$, LPS $(1 \mu \mathrm{g} / \mathrm{ml})$ was treated for 1 hours at 37 ${ }^{\circ} \mathrm{C}$. At 1 hour after LPS treatment, the cells were collected, and NF-кB activation was determined using NF-кB (human p50/p65) Combo Transcription Factor Assay Kit (Cayman
Chemical, Ann Arbor, MI) with manufacturer's instructions.

\section{Westem blot}

RAW 264.7 cells $\left(2 \times 10^{5}\right.$ cells/well $)$ in 10\% FBS-DMEM without phenol red were seeded in a 6 -well plate for 24 hours at $37^{\circ} \mathrm{C}$. Cells were washed with $1 \times$ PBS, replaced with fresh media, and then treated with the varying concentrations of ethyl acetate fraction for $30 \mathrm{~min}$. After $30 \mathrm{~min}$, LPS $(1 \mu \mathrm{g} / \mathrm{ml})$ was treated for 24 hours at $37^{\circ} \mathrm{C}$. Each cell was harvested for the analysis. The cells were lysed with lysis buffer $(50 \mathrm{mM}$ Tris-HCl pH 7.4, 150 mM NaCl, 1 mM EDTA, 1 mM EGTA, $10 \mu \mathrm{g} / \mathrm{ml}$ aprotinin, $10 \mu \mathrm{g} / \mathrm{ml}$ leupeptin, $5 \mathrm{mM}$ phenylmethylsulfonyl fluoride [PMSF], and 1 mM DTT) containing $1 \%$ Triton $\mathrm{X}-100$. Insoluble debris was removed by centrifugation at $12,000 \mathrm{rpm}$ for $15 \mathrm{~min}$ three times. Twenty five microgram protein extracted from the cells was separated on $15 \%$ Tris- $\mathrm{HCl}$ ready gel (Bio-Rad, Hercules, CA) following the manufacturer's instruction. Gels were transblotted on to PVDF membranes for western blot analysis. The membranes were blocked for non-specific binding for $90 \mathrm{~min}$ in block buffer $(5 \%$ non-fat milk and $0.1 \%$ Tween 20 in $1 \times$ Trisbuffered saline[TBS]) and then washed with $1 \times$ TBS solution $(0.1 \%$ Tween 20 in $1 \times$ TBS $)$. After $90 \mathrm{~min}$, the membrane was incubated with iNOS and COX-2 antibody at 1:1000 dilutions in antibody dilution buffer ( $3 \%$ non-fat milk, $1 \times$ TBS, $0.1 \%$ Tween 20) with gentle shaking at $4{ }^{\circ} \mathrm{C}$ for 16 hours and then washed with $1 \times$ TBS. After washing, the membrane was incubated with Phototope-HRP Western Blot Detection System, Anti-rabbit IgG, HRP-linked Antibody as the secondary antibody at 1:1000 dilutions in antibody dilution buffer (3\% non-fat milk and $0.1 \%$ Tween 20 in $1 \times$ TBS) for $4 \mathrm{~h}$ at the room temperature and then washed again. After washing, the membrane was treated with the detection agent (Amersham Biosciences) and immediately developed in Polaroid film.

\section{Statistical analysis}

All results were expressed as the mean \pm the standard deviation of triplicate analysis. Statistical comparisons were performed using the Student's t-test. Differences were considered significant at $\mathrm{p}<0.05$. 


\section{Results}

GC/MS analysis of the ethyl acetate fraction from $C$. officinale

The chemical compositions of the ethyl acetate fraction from $C$. officinale were analyzed by $\mathrm{GC} / \mathrm{MS}$, leading to comparison of the relative retention times and the mass spectra from data library (Wiley 275 Imass spectral database, Hewlett-Packard, 1995). GC/MS analysis resulted in the identification of forty three compounds (not shown). As shown in Fig. 1, among forty three compounds, the main components were eight including benzoic acid $(0.22 \%)$, 2-methoxy-4vinylphenol (27.2\%), vanillin (0.51\%), butyl phthalide (1.79\%), butylidene phthalide ( $0.81 \%)$, 2-propylphenol (6.68\%), butylidene-

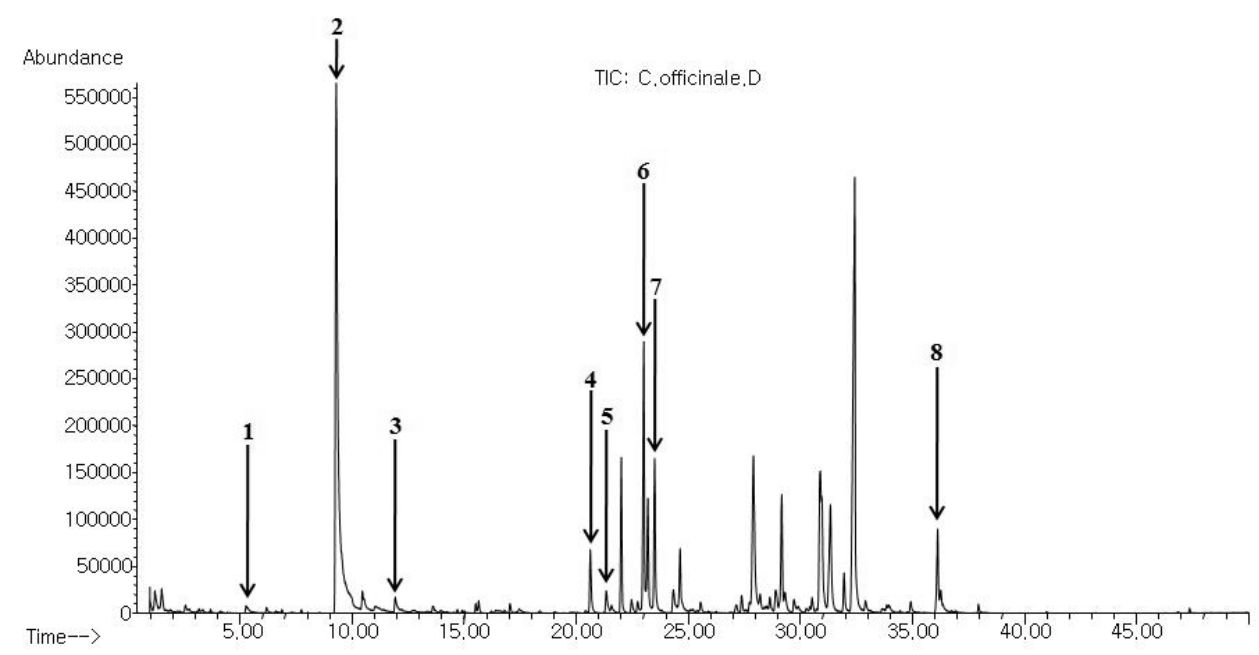

\begin{tabular}{|c|c|c|c|c|}
\hline & RT & Composition (\%) & Chemical name & Chemical structure \\
\hline 1 & 5.25 & 0.22 & Benzoic acid & \\
\hline 2 & 9.29 & 27.20 & 2-methoxy-4-vinylphenol & \\
\hline 3 & 11.93 & 0.51 & Vanillin & \\
\hline 4 & & & & \\
\hline & 20.0 & (an & 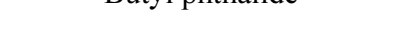 & \\
\hline 5 & 21.35 & 0.81 & Butylidene phthalide & \\
\hline 6 & 23.02 & 6.68 & 2-propylphenol & \\
\hline 7 & 23.51 & 4.05 & Butylidene-dihydro-phthalide & \\
\hline 8 & 36.13 & 2.45 & Linolic acid & \\
\hline
\end{tabular}

Fig. 1. Chromatogram and chemical composition of ethyl acetate fraction by GC/MS. 
dihydro-phthalide (4.05\%) and linolic acid (2.45\%)

In vitro cytotoxicity of ethyl acetate fraction from $C$. officinale against RAW 264.7 and THP-1 cell

The cell viability was determined by MTT assay. RAW 264.7 and THP-1 cells were treated with various concentrations of ethyl acetate fraction for 24 hours. As shown in Fig. 2A, ethyl acetate fraction did not exhibit cytotoxicity at the range of 12.5-200 $\mu \mathrm{g} / \mathrm{ml}$ against RAW 264.7 and THP-1 cells. This dose-range was used for the treatment of ethyl acetate fraction in the further experiments.

Ethyl acetate fraction from $C$. officinale inhibits the production of NO and $\mathrm{PGE}_{2}$ by suppressing iNOS and COX-2 expression in LPS-stimulated RAW264.7 cells

To determine whether ethyl acetate fraction from $C$.

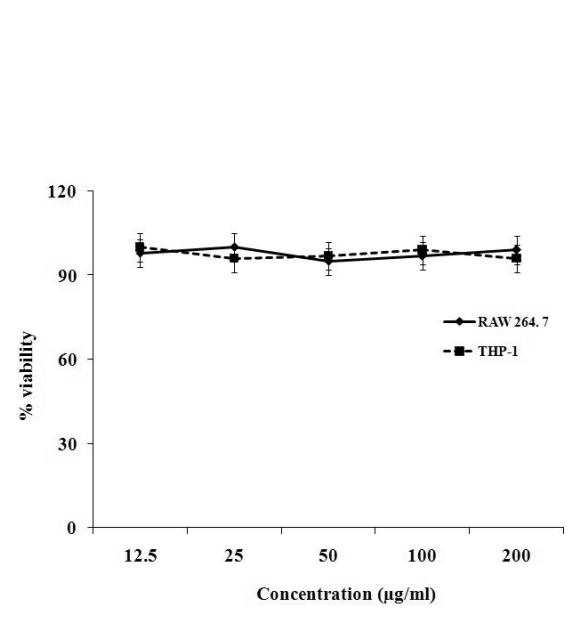

(A)

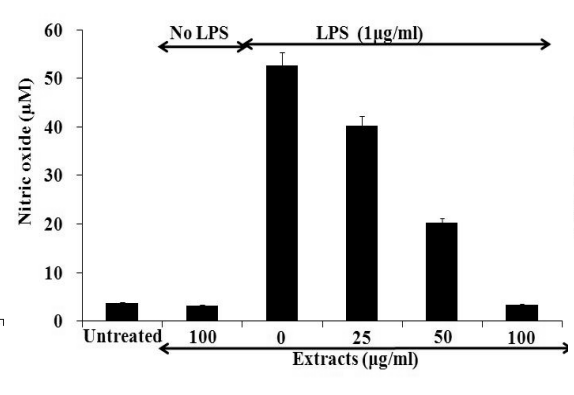

(B)

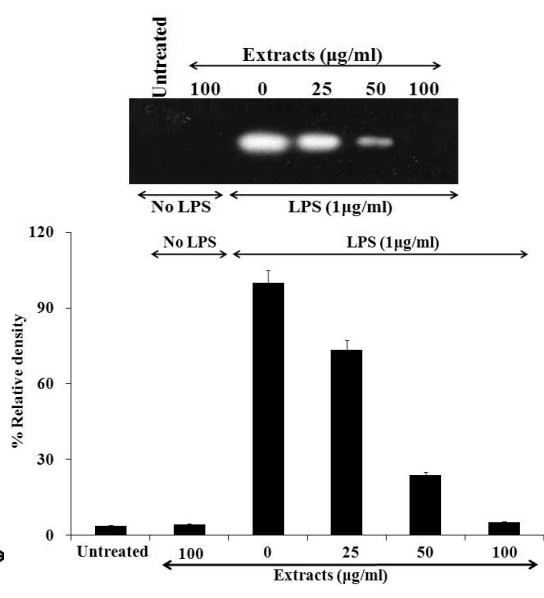

(C)

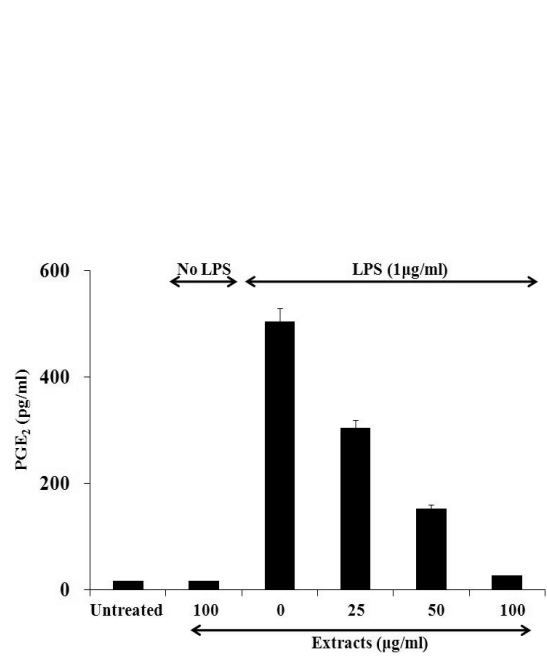

(D)

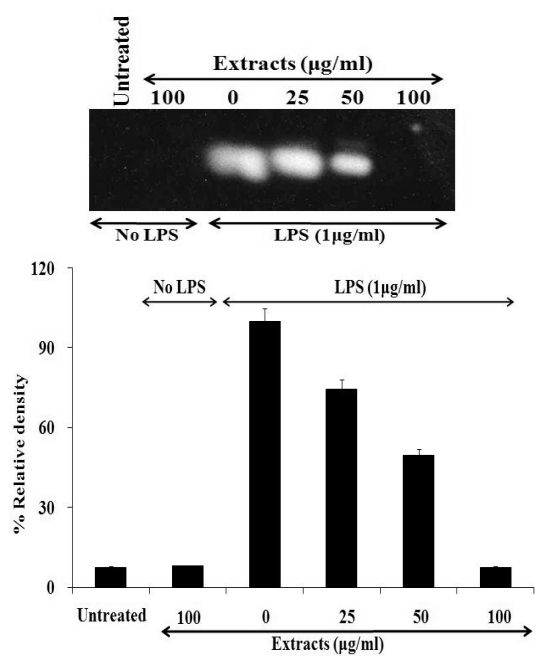

(E)

Fig. 2. Cytotoxicity (A) and the effect of different concentrations of ethyl acetate fraction from C. officinale in NO (B) and PGE2 (D) production by suppressing iNOS (C) and COX-2 (E) expression by LPS-stimulated RAW 264.7 macrophage cells. RAW 264.7 cells were pretreated with the varying concentrations of ethyl acetate fraction and then treated with LPS $(1 \mu \mathrm{g} / \mathrm{ml})$. The media for the measurement of NO and PGE2 and the cells for western blot of iNOS and COX-2 were collected at 24 hours after LPS treatment. In western blot, each well was loaded with $25 \mu \mathrm{g}$ protein. \% relative density of expressed iNOS and COX-2 bands in western blot was calculated by the density using the software Un-SCAN-IT gel Version 5.1 (Silk Scientific, Inc.). 
officinale inhibit the production of NO induced by LPS which plays a central role in the inflammatory response, RAW264.7 cells were pretreated with the ethyl acetate fraction for $30 \mathrm{~min}$ and then stimulated with LPS $(1 \mu \mathrm{g} / \mathrm{ml})$. After stimulation for 24 hours, the cell medium was harvested, and the production of NO was measured using the Griess assay. RAW264.7 cells unstimulated by LPS and treated with ethyl acetate fraction alone without LPS secreted basal level of NO, while the stimulation of LPS without ethyl acetate fraction resulted in an increase in NO production. Ethyl acetate fraction significantly inhibited the production of LPS-induced NO in a concentration-dependent manner. At the concentration of ethyl acetate fraction $(100 \mu \mathrm{g} / \mathrm{ml})$, NO production induced by LPS was reduced to approximately basal levels compared with RAW264.7 cells unstimulated by LPS and treated with ethyl acetate fraction alone without LPS (Fig. 2B). To further understand the inhibitory effects of ethyl acetate fraction on NO production, western blot analysis was performed to determine the expression of iNOS protein at 24 hours after LPS stimulation. Under unstimulation of LPS, iNOS protein was not detectable. Ethyl acetate fraction attenuated the iNOS expressions in LPS-stimulated RAW264.7 cells in a concentration-dependent manner (Fig. 2C). This implies that ethyl acetate fraction inhibited NO production by suppressing iNOS expression in LPS-stimulated RAW264.7 cells.

$\mathrm{PGE}_{2}$ is an inflammatory mediator which is produced from the conversion of arachidonic acid by cyclooxygenase. In a variety of inflammatory cells, including macrophages, COX2 is induced by cytokines and other activators, such as LPS, resulting in the release of a large amount $\mathrm{PGE}_{2}$ at inflammatory sites (Yoon et al., 2009). Therefore, we evaluated the inhibitory effects of ethyl acetate fraction against $\mathrm{PGE}_{2}$ production in LPS-stimulated RAW264.7 macrophages. When stimulated with LPS $(1 \mu \mathrm{g} / \mathrm{ml})$ without the ethyl acetate fraction for 24 hours, RAW264.7 macrophages produced $\mathrm{PGE}_{2}$ by $504 \mathrm{pg} / \mathrm{ml}$ in the culture medium. However, ethyl acetate fraction significantly inhibited the production of LPS-induced $\mathrm{PGE}_{2}$ by $40 \%$ at $25 \mu \mathrm{g} / \mathrm{ml}, 70 \%$ at $50 \mu \mathrm{g} / \mathrm{ml}$, and $95 \%$ at $100 \mu \mathrm{g} / \mathrm{ml}$. RAW264.7 cells unstimulated by LPS and treated with ethyl acetate fraction alone without LPS secreted basal level of $\mathrm{PGE}_{2}$ (Fig. 2D). To determine whether inhibition of $\mathrm{PGE}_{2}$ production by ethyl acetate fraction was mediated by regulation of COX-2 expression, western blotting analysis was performed. As shown in Fig. 2E, the expression of COX-2 protein was significantly increased in macrophages treated with LPS $(1 \mu \mathrm{g} / \mathrm{ml})$ compared to the unstimulated cells. However, ethyl acetate fraction significantly inhibited the production of LPS-induced $\mathrm{PGE}_{2}$ by $26 \%$ at $25 \mu \mathrm{g} / \mathrm{ml}$, $50 \%$ at $50 \mu \mathrm{g} / \mathrm{ml}$, and $92 \%$ at $100 \mu \mathrm{g} / \mathrm{ml}$. This implies that ethyl acetate fraction inhibited $\mathrm{PGE}_{2}$ production by suppressing COX-2 expression in LPS-stimulated RAW264.7 cells.

\section{Ethyl acetate fraction $C$. officinale inhibits the release of TNF- $\alpha$ in LPS-stimulated THP-1 cells.}

TNF- $\alpha$ is also able to induce apoptotic cell death, to induce inflammation, and to inhibit tumorigenesis and viral replication. Dysregulation and, in particular, overproduction of TNF- $\alpha$ have been implicated in a variety of human diseases, as well as cancer (Locksley et al., 2001). As shown in Fig. 3, LPS released TNF- $\alpha$ by $1457.8 \mathrm{pg} / \mathrm{ml}$ in THP-1 cells in absence of ethyl acetate fraction. However, ethyl acetate fraction significantly inhibited the release of LPS-induced TNF-a by $21 \%$ at $25 \mu \mathrm{g} / \mathrm{ml}, 40 \%$ at $50 \mu \mathrm{g} / \mathrm{ml}$, and $60 \%$ at 100 $\mu \mathrm{g} / \mathrm{ml}$. THP-1 cells unstimulated by LPS and treated with ethyl acetate fraction alone without LPS secreted basal level of TNF-a.

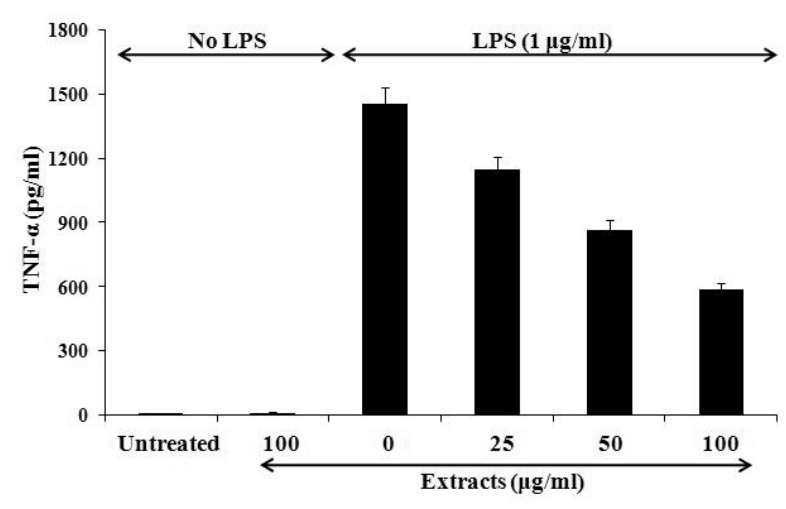

Fig. 3. Inhibitory effect of ethyl acetate fraction from $C$. officinale on TNF-a release in LPS-stimulated THP-1 cells. THP-1 cells were pretreated with the varying concentrations of ethyl acetate fraction and then treated with LPS $(1 \mu \mathrm{g} / \mathrm{ml})$. The media for the measurement of TNF- $a$ was collected at 24 hours after LPS treatment. 


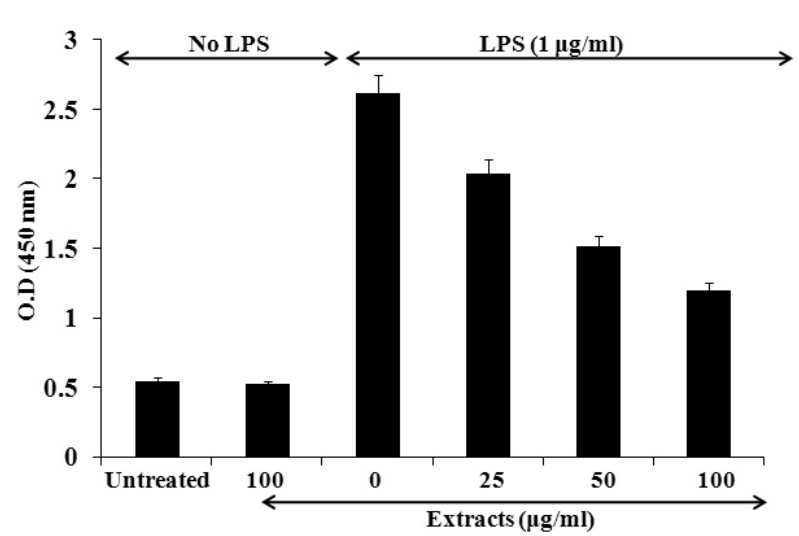

(A)

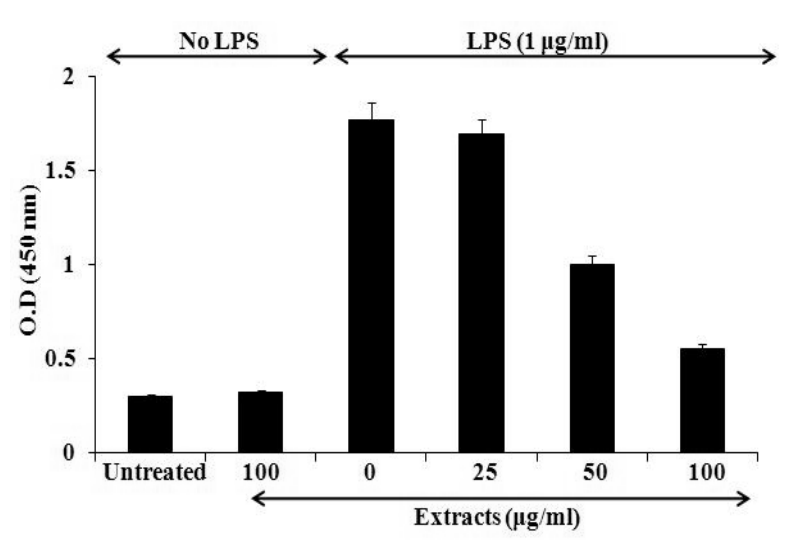

(B)

Fig. 4. Inhibitory effect of ethyl acetate fraction from $C$. officinale against NF-кB activation in LPS-stimulated THP-1 cells. (A) Assay of NF-кB (human p50) and (B) Assay of NF-кB (human p65) from the nuclear fraction of LPS-stimulated THP-1 cells. THP-1 cells were pretreated with the varying concentrations of ethyl acetate fraction and then treated with LPS (1 $\mu \mathrm{g} / \mathrm{ml})$. The cells were collected at 1 hour after LPS treatment.

\section{Ethyl acetate fraction from $C$. officinale inhibits NF- $\mathbf{K}$ activation}

$\mathrm{NF}-\mathrm{KB}$ is an important transcription factor to regulate pro-inflammatory mediators such as $\mathrm{NO}, \mathrm{PGE}_{2}$ and TNF- $\mathrm{a}$ in activated macrophage (Jung et al., 2009). Therefore, the inhibitory effect of ethyl acetate fraction against NF-кB activation was investigated using NF-кB (human p50/p65) Combo transcription factor Assay kit which is non-radioactive, sensitive method for detecting specific transcription factor DNA binding activity in nuclear extracts. Compared with LPS-stimulated cells without ethyl acetate fraction, it inhibited the nuclear translocation of NF-кB p50 by $22 \%$ at $25 \mu \mathrm{g} / \mathrm{ml}, 42 \%$ at $50 \mu \mathrm{g} / \mathrm{ml}$, and $54 \%$ at $100 \mu \mathrm{g} / \mathrm{ml}$ (Fig. $4 \mathrm{~A}$ ). Also, ethyl acetate fraction inhibited the nuclear translocation of NF-кB p 65 by $5 \%$ at $25 \mu \mathrm{g} / \mathrm{ml}, 44 \%$ at $50 \mu \mathrm{g} / \mathrm{ml}$, and $69 \%$ at $100 \mu \mathrm{g} / \mathrm{ml}$ (Fig. 4B). THP-1 cells unstimulated by LPS and treated with ethyl acetate fraction alone without LPS secreted basal level of NF-кB p50 and p65 activation. From these results, it is thought that the inhibitory effect of ethyl acetate fraction against NF-кB activation may result in the suppression of inflammatory mediators such as $\mathrm{NO}, \mathrm{PGE}_{2}$, TNF$a$, iNOS and COX-2.

\section{Discussion}

Plant products have been historically important in the prevention and treatment of illness. Plants are a rich source of active ingredients for health care products, with many blockbuster drugs being directly or indirectly derived from plants (Rishton, 2008). The present study was undertaken to elucidate the pharmacological and biological effects of Cnidium officinale Makino on the production of inflammatory mediators by inhibiting NF- $\mathrm{KB}$ activation in macrophages. Macrophages actively participate in inflammatory responses by releasing pro-inflammatory cytokines like TNF-a and inflammatory factors such as $\mathrm{NO}$ and $\mathrm{PGE}_{2}$ (Bosca et al., 2005). Therefore, inhibition of these inflammatory molecules has been considered as a novel candidate of an anti-inflammatory drug.

NO is a free radical that plays a pivotal role in cell survival and death through regulation of $\mathrm{NF}-\kappa \mathrm{B}$, and plays a various pro-inflammatory effects on many cell types. High levels of NO generated by iNOS, however, have been shown to be cytotoxic in studies of many inflammatory diseases, including atherosclerosis, rheumatoid arthritis, diabetes, septic shock, transplant rejection, and multiple sclerosis, leading to cell death (Moncada, 1999). iNOS expression in macrophages is activated by specific inducers and participates in the pathology of inflammatory diseases (Buttery et al., 1994). In our study, ethyl acetate fraction from $C$. officinale inhibited NO production by suppressing iNOS expression in LPS-stimulated RAW264.7 cells.

$\mathrm{PGE}_{2}$ is an inflammatory mediator generated at inflammatory 
sites by COX-2, known as prostaglandin endoperoxide synthase, and induces the development of many chronic inflammatory diseases, such as cardiovascular disease, cancer, and rheumatoid arthritis (Turini and DuBois, 2002). Administration of anti-inflammatory agents which inhibit COX-2 activity has been shown to be beneficial in preventing and treating these diseases (Rocca and FitzGerald, 2002). In the present study, ethyl acetate fraction inhibited $\mathrm{PGE}_{2}$ production by suppressing COX-2 expression in LPS-stimulated RAW264.7 cells. These data imply that the inhibition of NO and $\mathrm{PGE}_{2}$ production by ethyl acetate fraction might be due to suppressing the high expression of iNOS and COX-2 during the activation of macrophages by LPS.

TNF-a is a major pro-inflammatory cytokine in various immune cells such as macrophages, monocytes and $\mathrm{T}$ cells, and have various pro-inflammatory effects in chronic inflammatory diseases such as rheumatoid arthritis and atherosclerosis (Andreakos et al., 2002). In this study, ethyl acetate fraction inhibited TNF-a release in LPS-stimulated THP-1 cells. This result suggests that ethyl acetate fraction effectively inhibited the generation of pro-inflammatory cytokines that are paramount in the generation of an inflammatory response in activated macrophages.

NF-КB is known to play a critical role in the regulation of cell survival genes and to induce the expression of inflammatory enzymes and cytokines, such as iNOS, COX-2 and TNF- $\alpha$ (Yoshimura, 2006). Furthermore, blocking the NF-кB transcriptional activity in the macrophage nucleus can suppress the expression of iNOS, COX-2, and pro-inflammatory cytokines (Yin et al., 2005). In NF-KB activation assay for elucidating the further mechanism underlying the pharmacological anti-inflammatory activity, ethyl acetate fraction inhibited the nuclear translocation of NF-кB p50 and $\mathrm{p} 65$. These results indicate the potential role of NF-KB in the suppression of inflammatory mediators such as $\mathrm{NO}, \mathrm{PGE}_{2}$ and TNF-a by ethyl acetate fraction from C. officinale. Therefore ethyl acetate fraction may be a potential drug for treating inflammatory diseases.

Our observations suggest that $C$. officinale has a strong anti-inflammatory property to inhibit $\mathrm{NO}$ and $\mathrm{PGE}_{2}$ production by suppressing the high expression of iNOS and COX-2 during the activation of macrophages by LPS and to inhibit TNF-a release via blocking NF-кB activation. Therefore C. officinale may be possible for the application to a potential drug for treating inflammatory diseases.

\section{Acknowledgement}

This work was supported by Basic Science Research Program through the National Research Foundation of Korea (NRF) funded by the Ministry of Education, Science and Technology (2011-0013786).

\section{Literature Cited}

Ahn, M.Y., K.S. Ryu, Y.W. Lee and Y.S. Kim. 2000. Cytotoxicity and L-amino acid oxidase activity of crude insect drugs. Arch. Pharm. Res. 23:477-481.

Andreakos, E., B. Foxwel and M. Feldmann. 2002. Is targeting Toll-like receptors and their signaling pathway a useful therapeutic approach to modulating cytokine-driven inflammation? Immunol. Rev. 202:250-265.

Banskota, A.H., Y. Tezuka, N.Y. Nguyen, S. Awale, T. Vobukawa and S. Kadota. 2003. DPPH radical scavenging and nitric oxide inhibitory activities of the constituents from the wood of Taxus yunnanensis. Planta Med. 69:500-505.

Bosca, L., M. Zeini, P.G. Traves and S. Hortelano. 2005. Nitric oxide and cell viability in inflammatory cells: a roll for $\mathrm{NO}$ in macrophage function and fate. Toxicology 208:249-258.

Buttery, L.D., T.J. Evans, D.R. Springall, A. Carpenter, J. Cohen and J.M. Polak. 1994. Immunochemical localization of inducible nitric oxide synthase in endotoxin-treated rats. Lab. Invest. 71:755-764.

Jeong, S.I., D.H. Kwak, S. Lee, Y.K. Choo, W.H. Woo, K.S. Keum, B.K. Choi and K.Y. Jung. 2005. Inhibitory effects of Cnidium offcinale Makino and Tabanus fulvus Meigan on the high glucose-induced proliferation of glomerular mesangial cells. Phytomedicine 12:648-655.

Jung, H.W., U.K. Seo, J.H. Kim, K.L. Leem and Y.K. Park. 2009. Flower extracts of Panax notoginseng attenuates lipopolysaccharide-induced inflammatory response via blocking of NF-kB signaling in murine macrophages. J. Ethnopharmacol. 122:313-319.

Libby, P., P.M. Ridker and A. Maseri. 2002. Inflammation and atherosclerosis. Circulation 105: 1135-1143. 
Lim, J.H., Y.M. Park, J.S. Kim, H.J. Jeong and E.W. Seo. 2011. Effect of Cnidium officinale extract on recovery capability of allergic contact-dermatitis in Rat. Korean J. Plant Res. 24:430-437 (in Korean).

Locksley, R.M., N. Killeen and M.J. Lenardo. 2001. "The TNF and TNF receptor superfamilies: integrating mammalian biology". Cell 104:487-501.

Menichini, F., F. Conforti, D. Rigano, C. Formisano, F. Piozzi and F. Senatore. 2009. Phytochemical compositon, anti-inflammatory and antitumour activities of four Teucrium essential oils from Greece. Food Chem. 115:679-686.

Moncada, S. 1999. Nitric oxide: discovery and impact on clinical medicine. Journal of the Royal Society of Medicine 92:164169.

Nathan, C. 2002. Nitric oxide as a secretary product of mammalian cells. FASEB J. 6: 3051-3064.

Pokharel, Y.R., Q.H. Liu, J.W. Oh, R. Woo and K.W. Kang. 2007. 4-Hydroxykobusin inhibits the induction of nitric oxide synthase by inhibiting NF-kB and AP-1 Activation. Biol. Pharm. Bull. 30:1097-1101.

Rishton, G.M. 2008. Natural products as a robust source of new drugs and drug leads: past successes and present day issues. Am. J. Cardiol. 101:43D-49D.

Rocca, B. and G.A. FitzGerald. 2002. Cyclooxygenases and prostaglandins: shaping up the immune response. Int. Immunopharmacol. 2:603-630.
Sim, J.S., J.B. Jeong, J.H. Lee, T.H. Kwon, Y.J. Cha and H.J. Jeong. 2010. Inhibitory effect of the phenolic compounds from apples against oxidative damage and inflammation. Korean J. Plant Res. 23:487-497.

Turini, M.E. and R.N. DuBois. 2002. Cyclooxygenase-2: a therapeutic target. Annu. Rev. Med. 53:35-57.

Yang, C.W., W.L. Chen, P.L. Wu, H.Y. Tseng and S.J. Lee. 2006. Anti-Inflammatory mechanisms of phenanthroindolizidine alkaloids. Mol. Pharmacol. 69:749-758.

Yin, H., F. Zhang, M. Yu, H. Cheng, J. Lin, Y. Gao, B. Han and L. Zhu. 2005. Beta-endorphin ameliorates synovial cell hyperfunction in the collagen-induced arthritis rat model by specific downregulation of NF-kappa B activity. Neuroendocrinology 81:10-18.

Yoon, W.J., Y.M. Ham, B.S. Yoo, J.Y. Moon, J.S. Koh and C.G. Hyun. 2009. Oenothera laciniata inhibits lipopolysaccharide induced production of nitric oxide, prostaglandin $\mathrm{E}_{2}$, and proinflammatory cytokines in RAW264.7 macrophages. J. Biosci. Bioeng. 107:429-438.

Yoshimura, A. 2006. Signal transduction of inflammatory cytokines and tumor development. Cancer Sci. 97:439-447.

Zhao, F., L. Wang and K. Liu. 2009. In vitro anti-inflammatory effects of arctigenin, a lignan from Arctium lappa L., through inhibition on iNOS pathway. J. Ethnopharmacol. 122:457-462.

(Received 26 October 2010; Revised 3 August 2011 ; Accepted 28 October 2011) 